\title{
Resilience of a contested high street: The changing image of Tunali Hilmi Street in Ankara, Turkey
}

\author{
Feyzan Erkip \\ Bilkent University
}

\begin{abstract}
Globally designed shopping spaces constitute a threat to on-street retail, which provides citizens a mix of activity patterns, including shopping, leisure and socializing. Consumers seem to prefer controlled mall environments due to problems in urban centers such as heavy traffic, limited parking, crowding, density and security concerns. The Turkish situation, however, indicates a different trend, with lively inner-city streets coexisting with highly acclaimed shopping malls. This paper addresses changing retail patterns on Tunali Hilmi Street, the first high street in Ankara, which reflects socio-economic and cultural dynamics of the last two decades in urban Turkey. This is a result of organic changes in the street's historical and demographic features as well as in Turkey's broader political and cultural environment. Since the millennium, the street has lost its distinctive quality as well as much of its upper-class clientele. The new visitor profile has been perceived by previous users as an invasion and threat to modern urban life. Recently, immigrants and refugees are starting to be seen on the street due to a nearby immigration office, which has caused further reaction. The paper's extended timespace analysis of Tunali Hilmi Street reflects an overall shift in urban life in Turkey.
\end{abstract}

\section{Introduction}

Increasing shopping alternatives in urban areas around the world constitute a threat to traditional streets, which provide citizens a mix of activity patterns, including shopping, leisure and socializing. New forms of consumption spaces, mainly shopping malls, attract citizens more than traditional spaces for various reasons. Problems in urban centers such as heavy traffic, limited parking, crowding, density and security concerns contribute to this issue. Global and standardized consumption spaces are more often located on a city's periphery, and people evidently prefer such controlled environments both for shopping and leisure. There is an increasing concern about decaying innercity streets resulting in efforts to make them viable by governments. (See Talen \& Jeong, 2019, for the U.S.; Wrigley \& Dolega, 2011, for Britain; Baker \& Wood, 2010, for Australia cases; Nagy, 2001, for East Central Europe.)

In contrast, Turkish people seem to use both new shopping malls and older street functions, but use them for different purposes (Ozuduru et al., 2014). Thus, the Turkish situation indicates a different trend, with lively inner-city streets co-existing with highly acclaimed shopping malls (Erkip et al., 2014; Ozuduru et al., 2014). This general trend is affecting streets' retail development. As Talen and Jeong (2019) suggest "main street" functions as a public space providing "street activity, economic development, diversity and social connection" and should be supported. 
Here, a brief note on public character of streets seems necessary. Streets are considered as one of the main public spaces in the city along with other open spaces such as parks, plazas and urban squares. In her extensively influential work, Jacobs (1961) praises the publicness of streets as a guarantee of civic life. However, the freedom of expression and equal access attributed to streets-as well as other public spaces-have been challenged by many others with the basic claim that there has always been a limit to publicness considering the multifaceted character of this concept. Hence, publicness is a matter of degree where power relations and the social actors define publicness in a certain context (Kirby, 2008; Staeheli \& Mitchell, 2007). Carmona (2015) focusing on the need for a "new paradigm" proposes a "new narrative and a new normative" based on local conditions. It seems appropriate to assume that the streets of Ankara (as with many other cities in today's world) have a limited publicness due to increasing segregation, surveillance and limits to freedom. However, Tunali Hilmi Street (hereafter Tunali) was established with exclusionary attitudes from the start, rather than being a public space. The specific conditions that have causes and change this feature of Tunali deserve further analysis.

In an earlier study, I claimed that the modernity provided by shopping malls attracted Turkish people due to the poor conditions of streets in the urban core. In a sense, they served as modern public spaces that were awaited by citizens (F. Erkip, 2003). For this reason, Tunali as a high street seems to have been influenced more by the mall development than other retail streets are. ${ }^{1}$ Via a thorough analysis of the various features of Tunali, I explore the question of what makes a high street resilient against urban transformations.

Tunali is short-only about $1 \mathrm{~km}$ - and is located in a prestigious and high-income neighborhood of Ankara (Turkey's capital city) called Kavaklidere. It starts at the junction of Esat Street and ends at Karum, the first shopping mall in Ankara, which was built in 1989. (see Figure 1.) This area was dominated by the homes of high-income residents when it was first redeveloped in the 1960s, and it began to change when Tunali became the choice of high-end clothing stores and European-style cafés in the late 1980s. With its location, this mix created a shopping sub-center in Ankara, especially attractive to the affluent. ${ }^{2}$ Tunali's transformation accelerated when a Sheraton Hotel and Karum Shopping Mall were built on the land of a previous vineyard and winery. An urban parkKugulupark (Swan Park)-lies across the street from the mall, which makes that end of Tunali also desirable for strolling.

Tunali is resilient in its continuous transition, and has transformed from modern to traditional during the last two decades. Inherent features of the neighborhood such as demographics, retailers' adaptive strategies, community and governance models help to define the street's character. However, urban policies and the need for retail to adapt to changes in the consumer demand structure are major causes of Tunali's transformation.

With leisure-retailing the dominant activity, events and activities are mostly defined by and change according to the street's retail structure; and constant shop changes and "retail drift" make place attachment temporary and low. With frequent intervention on the street-such as traffic and parking regulations-local government policies intensify the feeling of transience, and together with newly emerging retail spaces, cause the street to lose its high-street quality.

Due to the lack of sufficient and reliable data on retail businesses and their turnover rates, we observed and documented the stores on Tunali and some adjacent streets in 2010 (F. Erkip \& Kizilgun, 2011). Since then, being a participant observer and interviewing key informants helped me to be informed about the rate and direction of change. Long-term users-clients and shop ownersare the major sources of interviews. I searched social media to trace changing opinions about Tunali Hilmi, which appears to be an attractive destination for posts on modernity of Ankara's citizens and the distinctive qualities of Tunali. ${ }^{3}$ In this paper, I elaborate on the tensions between spatial distinction and publicness through the Tunali case and call attention to the evolving character of the street. In keeping with the development of the retailing literature, this can be approached through the lens of resilience. 


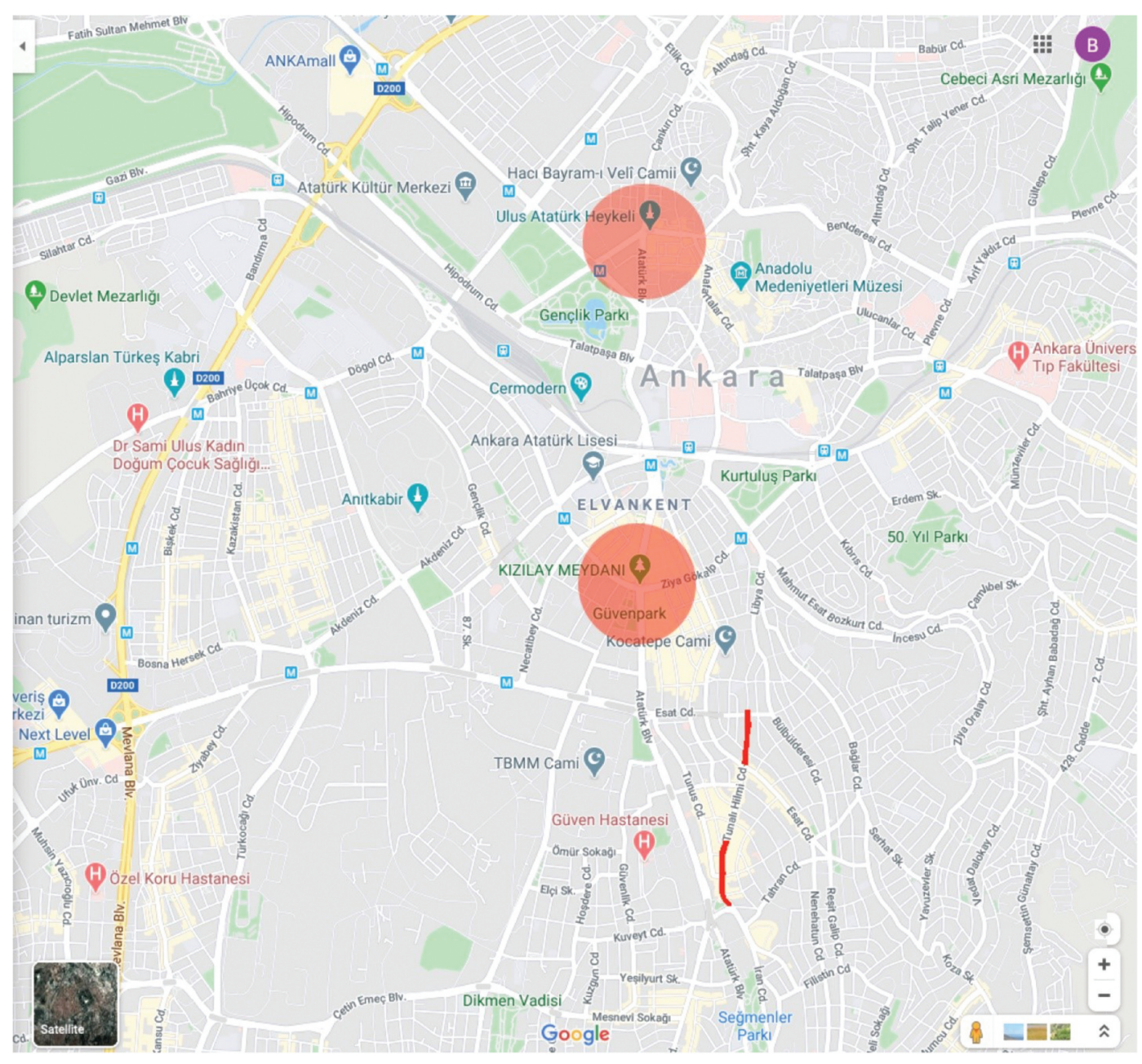

Figure 1. Tunali Hilmi Street and the CBD of Ankara (adapted from google.maps).

\section{Urban resilience and street retailing}

Resilience is a concept extensively adopted by many disciplines, including urban studies. It became an appealing concept to cover the complexity and ever-lasting transformation of cities. Originating from the ecological sciences, it was first used only in the context of physical structures and disasters (Holling, 1973). Researchers working on urban areas eagerly adopted this concept and started using it as a replacement for "sustainability" as it seemed to be more promising for application to complex systems, which are not easy to sustain when they face shocks and threats (see for example, Davidson et al. (2019) and Ercoskun-Yalciner and Ozuduru (2014). Instead, resilience provided them the opportunity to discuss the possibilities of continuous recovering and transforming into new forms and structures. Davidson et al. (2019) claim that resilience could be considered "as a component of sustainability" toward a progressive definition which the complexity of cities necessitates (see also Vale, 2014; Weichselgartner \& Kelman, 2014). Considering the ecological and natural threats which might affect cities and citizens in many ways, it is not surprising that international organizations such as UN-ISDR (International Strategy for Disaster Reduction), UN-Habitat, and The Rockefeller Foundation have been involved in developing strategies for making cities "more resilient" worldwide. 
However, there are concerns about its applicability to emerging issues without a thorough analysis of the specific conditions of a structure. In other words, "operationalizing resilience" is required (see Hernantes et al., 2019 for such an approach). As commented by Weichselgartner and Kelman (2014, p. 23), resilience in different urban context may have different meanings, where "the relationship between vulnerability and resilience is highly contextual." Vale (2014) adds that there are potential differences between "intended beneficiaries and who actually benefits" from the results of resilience policies. Resilience is about society and culture as well as economy and environment in a place-based approach (Mehmood, 2016). When social aspects are considered, flexible structures which respond to different needs of citizens differently-not equally or on the average-are more appropriate for adaptation, transformation and development. The normative aspect of resilience needs to be addressed as a part of the system itself. In that sense, all levels of government and community organizations should claim responsibility to achieve a just system of resilience.

As mentioned earlier, urban rhythms are mostly sustained by consumption activities and spaces under the capitalist logic (Karrlholm, 2009). Still, there is room for urban policies, and contestations between different citizen groups, depending on a city's political and cultural environment. Rhythms in an urban district are largely defined by urban transport policies such as public transport routes, parking lot locations and street pedestrianization (or the lack of it; Mulicek et al., 2016). These features affect the rhythms in an area and change visitors', workers' and residents' spatial experiences. Such features may also affect the visitor profile, as those who frequent a street are the social actors of daily life and are selective in their choices of an urban experience. Middleton (2009) suggests that urban pedestrian movements should be analyzed in experiential dimensions. The "temporalities of walking" for example, indicate a continuum rather than a single action (Vergunst, 2010; Wunderlich, 2008), involving the past, present and future. Sensory experiences-not only sights but also smell and noise-contribute to a street's attractiveness and rhythm (Zardini, 2005). For instance, the composition of food retailing on a street is important in defining the dominant aromas. Traffic noise leads to a different pace of walking than when one is accompanied by the sound of water gurgling or birds chirping. "A place's morphology, rhythm, smellscape, or soundscape are elements that can be seen as a resource for the performance of a certain practice" (Paiva et al., 2017, p.34).

In light of the above factors, Bourdieu's (1984) widely used concept “distinction" seems appropriate for analyzing our case. Social classes express themselves through certain spaces that fit their lifestyles-a particular habitus for each class-creating distinctions that reflect cultural and economic capital. Space covers more than just the physical qualities, yet spatial features help to sustain distinctive qualities. Distinctive social practices shared by certain groups play an important role on territorializing urban space (Atkinson, 2003). Zukin (2012) points out the role of collective memory in her analysis of a local shopping district in Amsterdam, which preserves its traditional character and cultural distinction.

Ankara is quite segregated along lines of income, education and socio-political issues, and Tunali itself is a good example of this situation as the most contested street (Atac, 2016; F. Erkip, 2010). Until recently, the high-street elite claimed the area, and there was a distinct class hierarchy between regular Tunali clientele and other citizens of Ankara. In a sense, it was dominated by the modern Turkish urbanite who opposes traditional values-reflected by conservative, religious views or looks-and adopts a Western way of life. Now, a new and different clientele and different stores are threatening that distinction. Two groups of citizens-modern and traditionally-oriented-clash and do not feel at ease in the current timespace. The concept of resilience should be discussed in this specific context from the perspectives of stakeholders and actors; citizens, retailers, NGOs and local administration. Each perspective provides a different aspect of resilience and to understand it, the history of Tunali and its transition over time should be presented. 


\section{The development of Tunali Hilmi Street}

Tunali Hilmi gained its commercial character in south Ankara after 1980. In the 1960s, the neighborhood developed rapidly as a high-income housing district with two- and three-story apartments. Previous to that time, the most distinctive features of the neighborhood were the Kavaklidere Vineyard and Winery (now the Sheraton Hotel and Karum Shopping Mall) (see Figure 1). At first, its inhabitants were bureaucrats and foreigners. In the 1970s, further transformation occurred. Buildings with six and seven stories were erected due to increasing housing demand. Kavaklidere adopted a new identity as an exclusive district, with cinemas, elegant restaurants and prestigious public buildings such as broadcasting headquarters. (A detailed analysis of Tunali's transformation between 1950 and 1980 can be seen in Resuloglu, 2011). Meanwhile Kizilay became the second and more modern retail district and reached its physical limits in the early 1980s. (See Figure 1 for the locations of two commercial districts, Ulus and Kizilay and Tunali in relation to them.) Since it is quite close to Kizilay, the neighborhood felt the pressure. Retail shops replaced housing units, first along Tunali, and then on side streets as rents on Tunali gradually increased. This was not a planned development but an invasion, and there was no attempt to prevent it (Resuloglu, 2011). This uncontrolled commercial change disturbed the high-income residents and eventually many moved to newly emerging gated communities outside the urban core. By the 1990s, Tunali's profile had completely changed; while the number of residences started to decrease and former flats had become offices, some side streets sustained their residential character. Tunali itself had become a distinctive commercial sub-center, with luxury domestic and international brands, commerce and banking offices and cultural spaces such as movie theaters and art galleries. In other words, the street became Ankara's first modern high street.

Tunali's retail character has changed a few times; first it was a high street boasting domestic brands, then some of those stores were replaced with eating spaces. By the early 1990s, the opening of new shopping malls lured citizens away from the city center, and attracted high-end stores and global brands (F. Erkip, 2003). This affected Tunali more than other retail streets in Ankara as an indication of its vulnerability in economic resilience. However, some national brands have returned to Tunali in the 2000s: two major clothing labels, Beymen and Vakko, led this trend and opened up multi-story shops in restored buildings, previously dwellings of affluent citizens. ${ }^{4}$ Very recently, Vakko left Tunali-except a special store for wedding dresses-and re-located to a newly restored shopping mall (see Table 1 for major transformations of the street).

Table 1. The transformation of Tunali in different periods.

\begin{tabular}{|c|c|c|c|c|c|c|}
\hline Periods & $\begin{array}{l}\text { Retail } \\
\text { density }\end{array}$ & User profile & Retail features & Cultural facilities & Physical features & Dominant feature \\
\hline Before 1950 & None & $\begin{array}{l}\text { A few } \\
\text { residents }\end{array}$ & None & None & Mostly uninhabited & $\begin{array}{l}\text { Kavaklidere Vineyard and } \\
\text { Factory (1929) }\end{array}$ \\
\hline $1950-1970$ & $\begin{array}{l}\text { Very } \\
\text { low }\end{array}$ & $\begin{array}{l}\text { Residents and } \\
\text { a few retailers }\end{array}$ & $\begin{array}{l}\text { High quality } \\
\text { commerce/ } \\
\text { leisure }\end{array}$ & $\begin{array}{l}\text { Movie theaters, } \\
\text { theaters and art } \\
\text { galleries }\end{array}$ & $\begin{array}{l}\text { Residential } \\
\text { development }\end{array}$ & $\begin{array}{l}\text { Residential/cultural and } \\
\text { Kugulupark (1958) }\end{array}$ \\
\hline $1970-1990$ & Medium & $\begin{array}{l}\text { Residents/ } \\
\text { retailers and } \\
\text { visitors }\end{array}$ & $\begin{array}{l}\text { High-end } \\
\text { retailing }\end{array}$ & Less & $\begin{array}{l}\text { Increase in building } \\
\text { heights and number } \\
\text { of workplaces }\end{array}$ & $\begin{array}{l}\text { Residential/cultural/ } \\
\text { commercial and leisure }\end{array}$ \\
\hline $1990-2000$ & High & $\begin{array}{l}\text { Retailers and } \\
\text { visitors }\end{array}$ & $\begin{array}{l}\text { Mixed } \\
\text { retailers and } \\
\text { leisure } \\
\text { facilities }\end{array}$ & A few & Crowded & $\begin{array}{l}\text { Commercial/leisure and } \\
\text { Karum mall (1991) }\end{array}$ \\
\hline After 2000 & High & $\begin{array}{l}\text { Retailers and } \\
\text { a new mix of } \\
\text { visitors }\end{array}$ & $\begin{array}{l}\text { Mixed } \\
\text { retailers and } \\
\text { leisure } \\
\text { facilities }\end{array}$ & None & $\begin{array}{l}\text { Crowded and poorly } \\
\text { maintained }\end{array}$ & $\begin{array}{l}\text { Commercial and leisure } \\
\text { with fast turnover, } \\
\text { Immigration Office (2019) }\end{array}$ \\
\hline
\end{tabular}

Source: Adapted from Resuloglu (2011) and Ercoskun-Yalciner and Ozuduru (2014). 
Now, Tunali includes shops of various sizes and characters. In addition to stores with a street front, there are 14 indoor shopping arcades on Tunali, some of which have a great impact on the street's overall retail type and volume. ${ }^{5}$ For instance, Kugulu Pasaj, one of the oldest arcades on Tunali, has about 150 shops selling various goods and services. Most shops provide medium- to lowpriced traditional goods and services such as bijouteries, haberdashers and tailors.

Regardless of the retail composition, this has always been a busy street, with a steady stream of people browsing on weekdays, and more on weekends. (see Figure 2 for a street view). Tunali is an experience of contemplation, as well as a place of purpose, many of which are leisurely, such as meeting friends in a coffee shop or restaurant. One such coffee shop, Cafe des Cafes, celebrated its 20th anniversary in 2015 and invited long-term customers to share their memories:

"In 1995, it started its adventure as the first coffee shop on Tunali while there was no other example in Ankara and pastry shops were dominant." (anonymous)

"Our second home, in which we spent years, laughed, restored ourselves after a tiring day." (Ceren, O.D. and Pinar, G.)

"I remember our chat about similarities between Turkish and Greek cousins with my Greek project partner when we came here." (Sule, O.)

"I am grateful for this nice space to which I invited all my artist friends and project partners whom I met through art." (Mehmet, S.)

"When I first came here as a vegetarian, I was excited to see "the veggie burger" in the menu and appreciated you so much. Thanks Cafe des Cafes." (Meserret, Z.)

As exemplified above, Tunali has an extensive collection of memories, of residents from mostly affluent districts of Ankara who adopted a secular lifestyle (eksisozluk.com has numerous entries on this aspect of Tunali). (See Figure 3 for the street with New Year decorations.) People like to stroll on this street, especially at weekends. Yurtkuran (personal communication, April 5, 2016) claimed that the streets were overtaken at night by elements that discouraged casual strolling, especially drunkenness and trash. Karrlholm (2009) states that "territories need to be maintained and nursed in order to be effective, and the management of territories often involves strategies of time" (p. 434). Tunali lacks this strategy and night use is defined by the users themselves. Vendors and musicians operate at night, and one side street, with its many bars (namely Bestekar Street, see Figure 1) has been a youth hangout for years (see, Altay, 2007 for a detailed analysis of this experience). Mattson (2015) suggests that bars are subcultural amenities and liminal spaces. As such spaces are limited in Ankara, Bestekar has a special meaning for modern youth of Ankara. (eksisozluk.com contains various

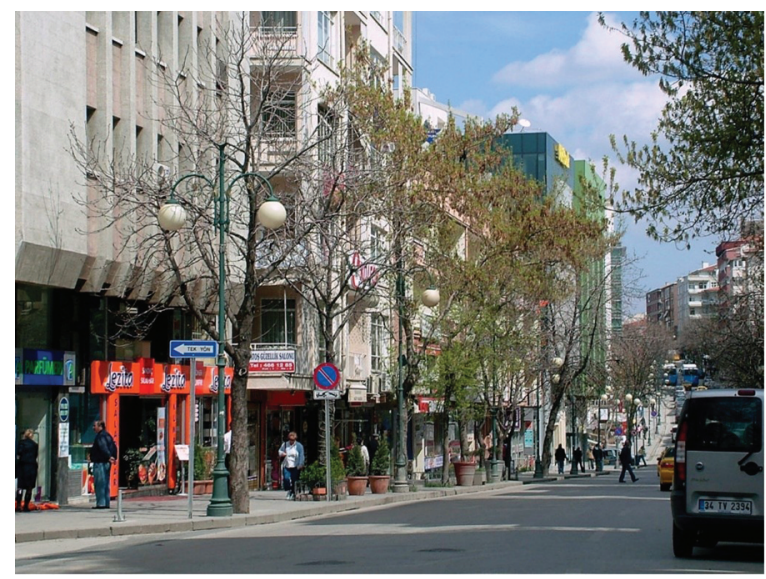

Figure 2. Tunali Hilmi on a weekday (https://www.gezirehberleri.com/ankarada-gezilecek-yerler/). 


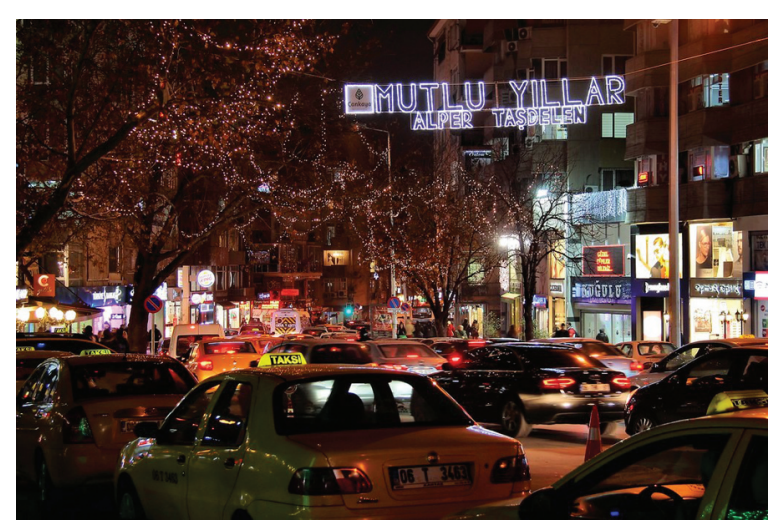

Figure 3. Tunali with New Year decorations (https//www.flickr.comphotosfranganillo24085775242inphotostream).

entries related to this character of the street). It also causes animosity among neighbors due to noise and the traffic load it has created.

It seems that shops in arcades are more resilient than on-street stores on Tunali, probably because the former provide traditional services and goods that stores on the street lack. They preserved their main feature as service providers during transformations. Yurtkuran (2016), however, sees the small floor space of arcade shops as a downside. For example, Mango, a Spanish retailer, is renovating four former small-scale stores into one larger store. Given the examples on Tunali, it appears that both large floor spaces and tiny spaces may experience survival challenges. In fact, only a handful of street-facing shops-fewer than 20-have survived more than 25 years, an indication of diminishing opportunity for a nostalgic visit. It also reflects the high turnover rate of the street's retailers. It is clear that shopping in an arcade is a more targeted activity than a leisurely stroll on the street outside.

Tunali is currently characterized by a mix of stores-mainly clothing, accessories and Europeanstyle cafés. Tunali's leisure aspect has been the least affected by crises and changes, and has even improved. However, store composition has changed frequently, devolving toward a lower price range. Although records are incomplete, the vacancy rate is generally low. Food and convenience, furniture and kitchen appliances, and cell phone and accessories stores have increased in the last decade. Developments in the telecommunications sector in recent years have added a new line of business, like elsewhere in the city. There has also been an increase in (mostly traditional) food retailers on Tunali, and a chain food center (Cagdas) has also opened there, which attracts residents from neighboring areas. These developments may create a positive spatial externality regarding street use and other retailers (Wrigley \& Dolega, 2011). However, it opens the street for a purposeful shopping activity (rather than strolling) and affects the visitor profile. Even the smellscape has changed with simit (a kind of Turkish bread) and döner (a rotisserie meat dish) the dominant smells. Clothing and footwear stores, on the other hand, have decreased, indicating a change in favor of shopping malls for these product groups. In fact, many visitors reveal that they come to Tunali for leisure and recreation, while they visit malls for their shopping needs (F. Erkip \& Kizilgun, 2011). A detailed analysis of the change in food stores indicates that there is a decrease in international (global) cuisine-the restaurants such as Tapas (serving Spanish food) and McDonalds closed. The restaurants serving alcohol also started to close from the decreasing demand. ${ }^{6}$

The decreasing quality of clothing and accessories stores and replacements of international cafés and eateries with more traditional and local chains, resulted in a diminished range of dining alternatives. Young people smoke nargile (a traditional way of smoking), drink Turkish tea and eat simit-a special and popular dough. (For an excellent account on the revival of 


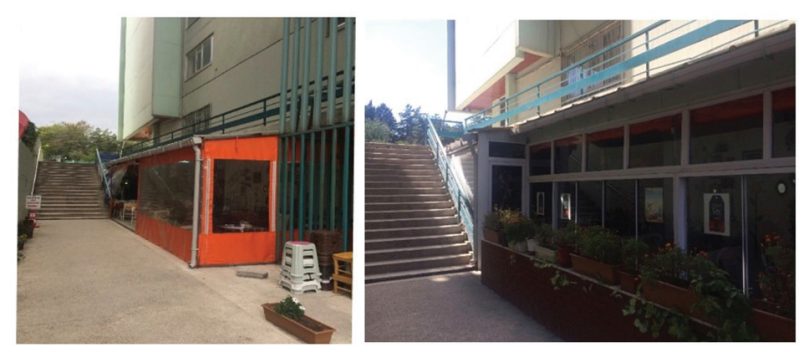

Figure 4. Merdivenalti Café 2016 and 2018 (author).

Turkish-style tea, see Ger \& Kravetz, 2009). A chain called Simit Sarayı (Simit Palace in English) dominates the urban café scene in many cities, including in Europe, as a smart mix of the tradition of having tea with simit, in a modernized café environment (F. Erkip \& Ozuduru, 2015). In the last decade, traditional Turkish cafés have also been making a comeback. An interesting example is a café built piecemeal in 2 years underneath a staircase which connects Tunali to the main Boulevard (Figure 4).

Tunali seems to be following an adaptation strategy of reviving traditional values, which attracts visitors of all social classes. This change challenges the distinctiveness of the street and pushes away the upper classes that once claimed the area. As a result, it has begun to lose its global character. Tunali used to have a distinct attraction for flaneurs-affluent idlers. Now, it has begun to resemble a regular working-class street with mixed-use shops rather than a high street.

Wrigley and Dolega (2011) base their analysis of resilience on high vacancy rates on retail streets in the UK. The number of "bad" vacancies (staying empty for more than two years) has increased in Tunali, especially for buildings with a large amount of floor space. ${ }^{7}$ The shopping mall, Karum however, has rebounded from the decline and high vacancy rate in the 2000s (due to new and more luxurious malls opening in Ankara) with a successful resilience strategy, specializing on nightgowns and party dresses. Two cafes inside the mall also changed hands and became home-style eateries.

Theaters and cultural spaces, however, which are one of the strongest reflections of a lively street, are non-existent; they were all closed by 2010. There were five movie theaters on Tunali in the 1990s -none of which is operating now. This is also an indication of cultural degradation of the street. Retailers and other informants claim that when Tunali was more fashionable, there were no empty stores; retailers who wanted to open a store paid a lump sum to the existing tenant to leave (Urunay, personal communication, May 16, 2010). Now, although the rents are still high on Tunali, no such deals are being made.

From the visitor's perspective, Tunali lacks many physical qualities of an enjoyable and safe street (Ghadimkhani, 2011) and is not much different from other streets in the CBD of Ankara. Especially after 2000s, lack of sidewalk maintenance and improper parking make walking difficult (F. Erkip \& Kizilgun, 2011). "Arrhythmic walking" is observed in Tunali due to obstacles, crowding and social gathering (Edensor's (2010). It became pedestrian-only on weekends for a short time in 1990. The direction of traffic flow has been changed many times by the GMA in the last 25 years, and since 2000 it has been a one-way street. Although retailers complain that this change has decreased the number of customers, there is no indication that this claim is accurate (Erkip et al., 2014). In fact, they focus on clients coming by car and stopping in front of the stores to buy items, not pedestrian shoppers.

Traffic load and parking problems are a major complaints of street retailers. There are few parking lots in the area, which is insufficient for the demand, and side parking-even double parking at crowded times-is not officially banned. In fact, traffic flow and direction have been the other important factors shaping the rhythm of the street. ${ }^{8}$ (See Table 2 for a review of Tunali's various features as a high street.) 
Table 2. Assessment of Tunali as a high street.

\begin{tabular}{ll}
\hline Priority considerations & \multicolumn{1}{c}{ Assessment of Tunali Hilmi } \\
\hline 1. Activity hours & Long during the day, limited at night \\
2. Appearance & Not very clean and well-maintained \\
3. Retailers & Decrease in the diversity, adaptive to demand \\
4. Vision and strategy & Weak communication and collaboration between actors, no specific local plans and strategies \\
5. Experience & Highly experienced retailers and strong image \\
6. Management & Not very effective \\
7. Merchandise & Decreasing quality and diversity, appropriate for the demand \\
8. Necessities & Limited parking space, no public restrooms, sufficient private amenities \\
9. Anchors & A few (Beymen, Karum and Çağdaş) \\
10. Networks and partnerships & Not strong, trust is low \\
11. Diversity & Multifunctional, limited retail diversity \\
12. Walking & Hard, not pedestrian friendly, not inclusive, narrow sidewalks, heavy car traffic, limited public \\
& transportation \\
13. Entertainment and leisure & High, variety of eating places and coffees \\
14. Attractiveness & High, it has a pulling power \\
15. Place assurance & Not very consistent, variable service levels \\
16. Accessibility & Private car, walking distance to CBD, limited public transportation, no bicycle \\
17. Place marketing & Not a special effort, limited communication of KAM, signage is not sufficient \\
18. Comparison/convenience & Shopping is not convenient \\
19. Recreational space & Kugulupark and Seymenler Park are in walking distance and public \\
20. Barriers to entry & Municipal conflicts, change in the visitor profile (decreasing demand for luxury goods) \\
21. Chain vs. Independent & Increase in the number of chain stores, still balanced \\
22. Safety/crime & Generally safe, increase in loitering and number of immigrants \\
23. Livability & Residences on side streets, sufficient residential services (school and hospital) \\
24. Adaptability & High, flexibility and high turnover rate of retail stores \\
25. Store development & Not common, reluctance to cooperate and coordinate in activities \\
\hline
\end{tabular}

Source: Adapted from Parker et al. (2017).

\section{Social resilience in the context of Tunali Hilmi Street}

Similar to malls attracting people from all classes and income groups when they first entered the urban scene in less affluent countries (see, F. Erkip, 2003 for Turkey; Butcher, 2012 for India), the distinction of strolling on high streets is being challenged by other classes. In the last decade, loitering around on-street cafés increased and became a common complaint of Tunali's visitors. ${ }^{9}$ This slippage in former distinctions is exactly what is happening on Tunali, with its changing sensory environment and new and mixed clientele. A very recent change is the opening of an immigration office on one of the side streets (See Figure 5 for the unaccustomed scenes of immigrants in front of
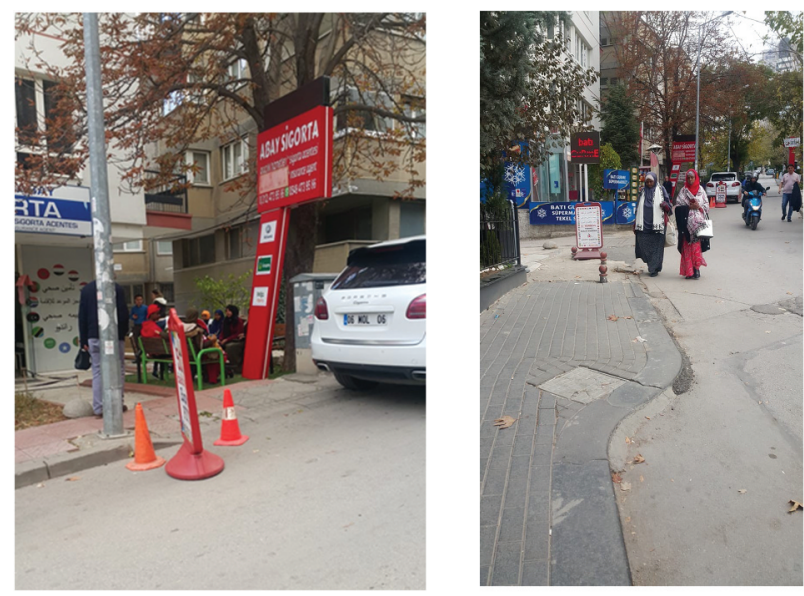

Figure 5. Two scenes from Tunali Hilmi after the opening of the Immigration Office (Kenan Ozduran). 
an insurance agency serving them.) Arabic language on the label of the agency is another sensitive spot for modern Turks, who consider themselves much apart from Arabs. Thus, immigrants and refugees, together with their families on Tunali constitute a further challenge to its distinct character; their presence has alienated the regular visitors due to increasing animosity of Turkish citizens toward Syrian refugees. ${ }^{10}$ Those who are more empathetic to refugee situation adopt an attitude of NIMBY (not in my backyard). This attitude reflects a discrimination against everybody except supposedly similar-minded people, mainly because they opt for a European modernity. (See Kirby, 2019 for a critique of Jane Jacobs for a similar attitude privileging her neighborhood in New York, regardless of the inequalities elsewhere in the city.)

This lack of tolerance to "others" was not due to conflicting political interests. Yet, Tunali became openly contested after 1994, when the Justice and Development Party (AKP) came to power in the Greater Municipality of Ankara (GMA) and conflict began between the GMA and the district municipality of Cankaya to which Kavaklidere district belongs, traditionally governed by the Republican People's Party (CHP.) The mayor of Ankara who was elected in 1994 for the first time kept this post more than two decades. Since the Greater Municipality claims responsibility for major traffic axes including Tunali, the conflict between municipalities at different levels disturbs retailers and citizens and harms the quality of the street. After AKP came to power in national elections in 2002, Ankara Municipality started to exercise its power more openly with the support of the central government. Batuman (2017) documented the harm done by the GMA claiming Ankara as a project for the Islamist city. In fact, the movement of the Immigration Office to one of the side streets of Tunali Hilmi was perceived as a challenge to its distinct character (Yurtkuran, personal communication, November 23, 2019). Kugulupark has always been important to the area as an oasis at a crowded junction as well as a symbol of Ankara (See Figure 6). Both Tunali Hilmi and Kugulupark became a meeting point for anti-government activities during the May 2013 Gezi Park events in Istanbul. (See Figure 7 for a Gezi protest on Tunali and Figure 8 for the police barricades bordering the park). Protesters camped in Kugulupark for several days until they were forcibly removed by police. Since then, many protest movements took place in this small park.

Tunali has a local community organization called Kavakliderem (KAM) begun by a few retailers. Such groups are not common in Turkey, and while KAM includes retail businesses and is concerned with Tunali's development, it seems to be more interested in beautifying the neighborhood in general. KAM has an office in a flat near Tunali and has a formal administrative structure. As a reflection of urban modernity, both genders are represented in a balanced way in KAM. Although it tries to promote a vision of participative citizenship and local action, it is not very effective in its relations with retailers and visitors.

Erman and Coskun-Yildar (2007) investigate wealthier neighborhood associations' roles in creating urban space, and KAM is among the few with some influence on local government. Yet its efforts have

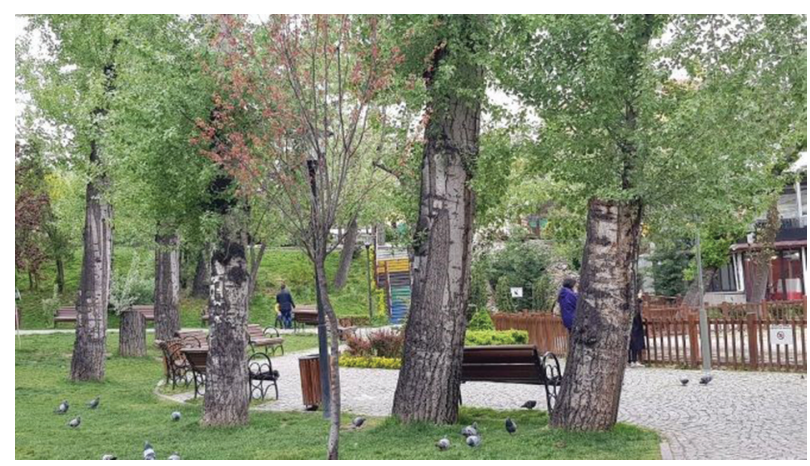

Figure 6. Kugulupark as an urban oasis (Gulnur Kaptanoglu) (www.gezirehberleri.com). 


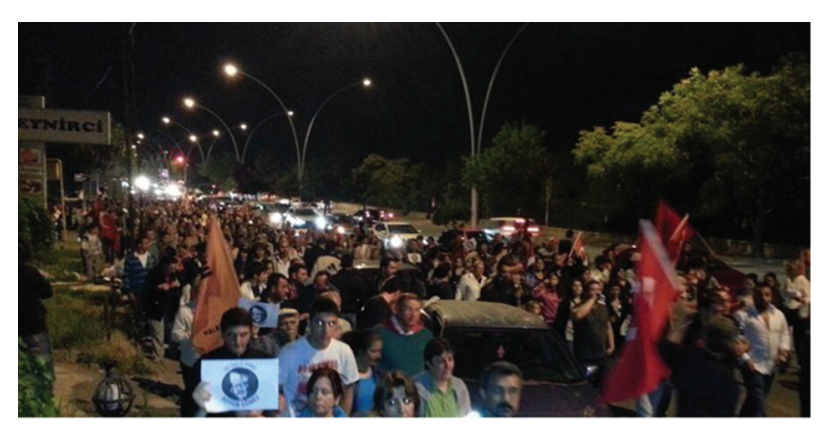

Figure 7. Gezi protests on Tunali Hilmi Street (t24.com.tr).
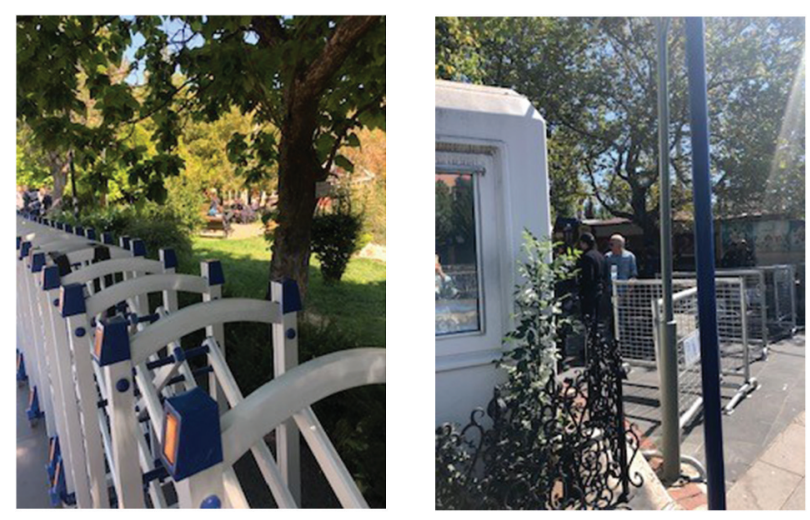

Figure 8. Police barricades as the border of Kugulupark (author).

proven limited for various reasons, two of which were its elitist approach favoring well-educated and affluent members and its ignorance of current retailers' changing needs. "Kavakliderem (KAM) was set up in 1996 by a leather-shop owner, who mobilized local store owners to compete with this new development by making Tunali Hilmi an attractive street in which to shop" (Erman \& Coskun-Yildar, 2007, p. 2556). KAM seemed to achieve its goal until a new wave of shopping malls drew business away from Karum, and thus away from Tunali. Thus, Karum and Tunali have both suffered in the battle with shopping mall development in Ankara. With its increasing number of gated communities and proximity to the new malls, suburban development is providing inhabitants a lifestyle outside the city center. Tunali suffered from this development as its high-income residents left the neighborhood and retailing remained the only function. Hence, the street had been forced to adopt a resilient strategy to attract new clientele. Economic resilience proved to be successful in adapting the retail scene to new visitors of the street with increasing number of local and traditional stores.

Now, however, KAM's goals of creating active citizens and a sense of community seem to have failed, as many visitors to the street either are not aware of or do not intend to participate in KAM's activities (F. Erkip \& Kizilgun, 2011). Reasons for this lack of interest are beyond the focus of this research and require a deeper analysis of the Turkish cultural context. Briefly, I will say that for historical reasons, citizens are reluctant to take part in local associations or volunteer actions. KAM's active members who engage in the association's vision are well-educated and affluent citizens, which may contribute to its elitist nature and alienates some of the street retailers. Although conflicts with the GMA continue to be a challenge, KAM has prevented the rentseeking behavior that dominated the previous street transformations. Protecting Kugulupark and 
transforming one of the vacant movie theaters into a live theater venue are among KAM's achievements. Yurtkuran (2016), however, feels that retailers are short-sighted and do not see that such public benefits nourish retailing. However, the complaints are mutual, as retailers think that KAM does not sufficiently address their problems (Erkip et al., 2014). Wrigley and Dolega (2011, p. 2347) point out the importance of "interdependencies between businesses and with local institutional structures." Sutton (2010) also discusses the potential for small business owners to influence retail restructuring and the importance of neighborhood associations in sustaining this potential. Local associations should be consulted and involved in municipal planning and policymaking and supported by local governments. When "facilitating adaptive resilience" is not a main concern for local organizations, retail dynamics are largely influenced by macro-economic changes. In the Tunali case, KAM and the local government act as rivals when the policy suggestions of the two parties involve different ideological standpoints. ${ }^{11}$

\section{Concluding remarks}

While Tunali reflects a transformation toward traditional retailing, that change is relatively recent and it is hard to tell how it will evolve. It seems that local and traditional features will persist and adversely affect its modern and global face. The decreasing number of high-income residents is a problem for Tunali, as its clientele-both during the day and in the evening-are mostly nonresidents and the visitor profile changes in line with the retail spaces and other shops and activities (or lack thereof). Currently, specific spaces that have survived the recent surge of retail change, such as Cafe des Cafes, are the remnants of the high street, and are in competition with the number of steadily increasing traditional cafés and shops.

Tunali is in continual transformation, and this instability does not facilitate its character as a high street. As mentioned earlier, it has suffered from conflicts caused by different political perspectives within the municipal government. It should also be noted that retailers' solutions to problems on the street are conflicting and the frosty relationship with KAM prevents a union that might help develop relevant proposals for the municipality.

As Spaans and Waterhout (2017) claim, long-term strategies of resilience necessitate a change in the mind-set and routines of stakeholders. Under the current circumstances, this does not seem to be the case for Tunali. At the very least, resilience planning should be holistic and involve all levels of government to adapt citizens and stakeholders to new situations. In terms of the roles of various actors in resilience of the street, one might conclude that retailers are successful in adapting to the changes in clientele and demand. KAM, representing a Western-style modernity however seems to have trouble in adapting to the new demand profile and resists the change on the street instead of supporting social resilience among retailers and visitors of the street.

In conclusion, the importance of maintaining Tunali as a high street should be underscored. It is part of Ankara'a history as a post-Ottoman city and has many symbolic features. Spatial memory however does not last long in Turkey due to the continuous destruction of nature, history and the built environment (Bora, 2016). A building older than 50 years is a rarity in Turkish urban areas and the experiences of generations are lost, regardless of their worth. This situation is definitely a threat to urban identity. High streets are being replaced with shopping malls, which are attractive mainly to the younger generations. Mixed-use streets have a better chance of survival as, with their diverse activity patterns and variety of retail types, they also attract people of all ages. Ankara's streets began to reflect a chaos of people, cars, noise, smell and similar retail experiences.

If one street is to be kept out of this pattern, the most appropriate candidate is Tunali, with its long history of modern urban development of Ankara. It constitutes a clash between Western modernization and its traditional counterparts in the prevailing Turkish urban development. This historical clash has been reflected in many cities, and Ankara, as the capital, has been the most contested city. Two opposing parties governing GMA and district municipalities contributed to this duality via urban policies and spaces. Recently, the immigration office was located near Tunali as if 
to challenge its modern look. In any case, it seems an intervention to Tunali's high-street character. Increasing publicness serves to democratize it, yet this change comes at the cost of deepened hostility toward others in a contested space.

However, the social sacrifice of preserving the distinct quality of an urban area requires further attention. Distinction comes with exclusion and resistance to social interaction with strangers, which defines the current situation of Tunali. Zukin (2012, p. 291) concludes that "urban cultural heritage, like the city itself, is a living social process. To survive, it must incorporate new as well as old traditions." Turkish citizens have become increasingly attached to their familiar "habitus" and many urban spaces reflect this feature. Given that streets-high or otherwise-are public spaces and should be accessible to all citizens, it is apparent that different social classes could interact everywhere in a city. The issue is making this interaction possible without creating animosity. It requires urban policies, which involve social resilience as well as physical and economic resilience. Turkish urban development lacks such comprehensive policies directed toward a mutual understanding between social classes. This lack is a serious threat for the future of urban life, especially when inequalities in the society posit themselves so strongly. Now, refugees and immigrants also require to share urban spaces and it is vital to attend to these issues to protect the character of and attachment to places. Our case is one such example which exhibits imminent consequences of neglecting social interactions and urban policies and governance.

\section{Notes}

1. Here, I need to explain my choice of terminology: high street or main street are used for inner city commercial streets of British and American cities, respectively. I believe that high street reflects Tunali's situation better; among many lively streets in the urban core, it once differentiated with its leisure and cultural offerings supporting social connections. (For an account of British town centers and high streets under the pressure of out-of-town and online retail, see Wrigley \& Lambiri, 2014.)

2. Although a few global brands are still located on Tunali, the impact of global consumption patterns is not very evident. Overall, only one-quarter of the brands available in Ankara are international, and they mostly prefer to locate in shopping malls. This indicates that street retail businesses in Ankara have a predominantly local character (Ercoskun-Yalciner \& Ozuduru, 2014).

3. Interviews with the owner of a coffee shop and previously a market on the street who is also one of the founding members of Kavakliderem-the NGO of the streets' retailers-various times between 2016 and 2019 and with a real estate agent on January 16,2010. We also interviewed with many visitors as a part of a project on urban retail in Ankara (F. Erkip \& Kizilgun, 2011). An additional source of information on Tunali is Eksisozluk-a collaborative website similar to www.reddit.com-which has hundreds of entries on Tunali's prominence for Ankara (eksisozluk.com).

4. Vakko was established as a national brand in 1938 by a hatmaker and started producing silk and cashmere scarves until it opened its first store in 1962 in Istanbul. Its first store in Ankara opened in 1973 in Kizilay. From then on it extended its product range from luxury accessories to clothing for various segments. Its closest competitor Beymen, also a national brand established as a family business opened its first store in 1971 in Istanbul and started selling its products in the same year in Ankara. Currently, both of them host global brands as a part of their retail supply in addition to products of local designers.

5. Arcades (pasaj (singular) in Turkish, originating from the French word for "passage") are a common and traditional form of commerce in Turkey, characterized by small stores selling various goods and services in a closed building with entrances from the street.

6. Reasons of this change in demand structure require further analysis in relation to Turkey's political climate under AKP rule during the last 15 years. While such exploration is beyond the scope of this study, we can conclude from recent indicators that the reasons are twofold: (1) obstacles and delaying tactics by local authorities; for example, a newly opened and elegant restaurant on Tunali struggled for months to obtain a license to serve alcohol (Yurtkuran, 2019). (2) And a more conservative visitor profile, geared more toward traditional spaces.

7. The bad vacancy rate is still relatively low on Tunali, but two large spaces have remained vacant for years. One was a movie theater named after the district, but that has been closed for more than a decade now. The name (Kavaklidere) is still intact as a reminder of Tunali's good days. Another large store in Karum shopping mall was previously rented by Zara but has been empty for more than five years. In both cases, high rent is the reason for this situation, which harms the street and the mall alike (Yurtkuran, 2016). 
8. It is shown that alternative traffic arrangements and control policies are feasible for Tunali to calm traffic and make walking easier (Dogan, 2014).

9. Income inequality and unemployment have been on the rise in Turkey, and have affected this situation. Loitering became common in many areas but Tunali is a more attractive target due to its leisure character. There are also organized loitering groups-using mostly under-age kids begging on affluent streets. There is not a visible intervention on these actions by the police or municipality officers.

10. According to the official figures, the number of Syrian refugees in Turkey was more than 3.5 million in 2019. (multeciler.org.tr), almost all living in urban areas. Ankara has a Syrian population of about 95,000. Due to unemployment, the urban poor see them as a threat for very competitive unqualified jobs. More affluent citizens have a negative attitude to both groups in general.

11. After 25 years of conflict between GMA and the district municipality, in 2019 local elections, the CHP candidate became the mayor of GMA. Hence, both GMA and the District Municipality of Kavaklidere started to be governed by the members of the same party. This change is expected to affect Tunali positively, since it was one of the most contested urban spaces between two opposing parties.

\section{Acknowledgments}

The author would like to thank Nesim Erkip, a participant observant who lived on and visited Tunali for years, for his valuable comments on the earlier drafts of the manuscript; Halil Yurtkuran, who lived and worked on Tunali since 1970 and was one of the founding members of KAM; and Bulent Batuman for his valuable remarks on distinction in Tunali context. The author is grateful for the comments of the editor and the two reviewers, which contributed to development of the main arguments of the manuscript. The author is also grateful to her friends and collective memories that made "going to Tunali" not simply a spatial but also a special experience.

\section{Disclosure statement}

No potential conflict of interest was reported by the author.

\section{About the author}

Feyzan Erkip is a retired professor who worked in the Department of Urban Design and Landscape Architecture and the Department of Interior Architecture of Environmental Design at Bilkent University. She received her PhD from the Department of City and Regional Planning at Middle East Technical University. She served as a member of the editorial board of Cities. She received URBANNET, Middle East Research Competition and TUBITAK research awards. Her research interests include urban transformations and consumption sites, leisure practices and spaces, environmental psychology and environmental design research.

\section{References}

Altay, D. (2007). Urban spaces re-defined in daily practices-'Minibar,' Ankara.” In L. Frers \& L. Meier (Eds.), Encountering urban places, visual and material performances in the city (pp. 62-80). Ashgate.

Atac, E. (2016). A divided capital: Residential segregation in Ankara. Metu Jfa, 33(1), 187-205. https://doi.org/10.4305/ METU.JFA.2016.1.10

Atkinson, R. (2003). Domestication by cappuccino or a revenge on urban space? Control and empowerment in the management of public spaces. Urban Studies, 40(9), 1829-1843. https://doi.org/10.1080/0042098032000106627

Baker, R. G. V., \& Wood, S. (2010). Towards robust development of retail planning policy: Maintaining the viability and vitality of main street shopping precincts. Geographical Research, 48(1), 65-74. https://doi.org/10.1111/j.17455871.2009.00622.x

Batuman, B. (2017). Siyasal İslamcı Belediye: Anlamı, İşlevi, Sınırları [Political Islamist Municipality: Its meaning, function, boundaries]. In T. K. Candan, R. Kolçak, G. Bolat, \& R. D. Çobanoğlu (Eds.), Ankara Rapor: Gökçek Dönemi Hasar Tespiti (1994-2017) [Ankara Report: Gökçek period damage determination] (pp. 44-77). Mimarlar Odasi Ankara Subesi.

Bora, T. (Ed.). (2016). Insaat ya Resulullah. Iletisim.

Bourdieu, P. (1984). Distinction: A social critique of the judgement of taste. Harvard University Press.

Butcher, M. (2012). Distinctly Delhi: Affect and exclusion in a crowded city. In T. Edensor \& M. Jayne (Eds.), Urban theory beyond the West (pp. 176-194). Routledge. 
Carmona, M. (2015). Re-theorising contemporary public space: A new narrative and a new normative. Journal of Urbanism: International Research on Placemaking and Urban Sustainability, 8(4), 373-405. https://www.tandfon line.com/doi/pdf/10.1080/17549175.2014.909518

Davidson, K., Nguyen, T. M. P., Beilin, R., \& Briggs, J. (2019). The emerging addition of resilience as a component of sustainability in urban policy. Cities, 92, 1-9. https://doi.org/10.1016/j.cities.2019.03.012

Dogan, M. (2014) Assessment and simulation of car access control policies in city center: The case of Tunali Hilmi Street in Ankara, MSc. Thesis in City Planning, Faculty of Architecture, METU.

Edensor, T. (2010). Walking in rhythms: Place, regulation, style and the flow of experience. Visual Studies, 25(1), 69-79. https://doi.org/10.1080/14725861003606902

Ercoskun-Yalciner, O., \& Ozuduru, B. (2014). Urban resilience and main streets in Ankara. IDPR, 36(3), $313-336$. https://online.liverpooluniversitypress.co.uk/doi/abs/10.3828/idpr.2014.18

Erkip, F. (2003). The shopping mall as an emergent public space in Turkey. Environment \& Planning A, 35(6), 1073-1093. https://doi.org/10.1068/a35167

Erkip, F. (2010). Community and neighborhood relations in Ankara: An urban-suburban contrast. Cities, 27(2), 96-102. https://doi.org/10.1016/j.cities.2009.10.003

Erkip, F., \& Kizilgun, O. (2011). Kentlerin Surdurulebilirligi icin Perakende Sektorunun Planlanmasi [Planning of Retail Sector for Urban Sustainability]. 108K614 project reports, Tubitak, Sobag. (Unpublished project report). TUBİTAK.

Erkip, F., Kizilgun, O., \& Mugan-Akinci, G. (2014). Retailers' resilience strategies and their impacts of urban spaces in Turkey. Cities, 36, 112-120. https://doi.org/10.1016/j.cities.2012.12.003

Erkip, F., \& Ozuduru, B. H. (2015). Retail development in Turkey: An account after two decades of shopping malls in the urban scene. Progress in Planning, 102, 1-33. https://doi.org/10.1016/j.progress.2014.07.001

Erman, T., \& Coskun-Yildar, M. (2007). Emergent local initiative and the city: The case of neighbourhood associations of the better-off classes in post-1990 urban Turkey. Urban Studies, 44(13), 2547-2566. https://doi.org/10.1080/ 00420980701558426

Ger, G., \& Kravetz, O. (2009). Special and ordinary times-Tea in motion. In E. Shove \& F. Trentmann (Eds.), Time, consumption and everyday life (pp. 189-202). Berg Publishers.

Ghadimkhani, P. (2011) Increasing walkability in public spaces of city centres: The case of Tunali Hilmi Street, Ankara. MSc. Thesis in Urban Design, Faculty of Architecture, METU.

Hernantes, J., Marana, P., Gimenez, R., Sarriegi, J. M., \& Labaka, L. (2019). Towards resilient cities: A maturity model for operationalizing resilience. Cities, 84, 96-103. https://doi.org/10.1016/j.cities.2018.07.010

Holling, C. S. (1973). Resilience and stability of ecological systems. Annual Review of Ecology and Systematics, 4(1), 1-23. https://doi.org/10.1146/annurev.es.04.110173.000245

Jacobs, J. (1961). The death and life of great American cities. Vintage Books.

Karrlholm, M. (2009). To the rhythm of shopping-On synchronization in urban landscapes and consumption. Social and Cultural Geography, 10(4), 421-440. https://doi.org/10.1080/14649360902853254

Kirby, A. (2008). The production of private space and its implications for urban social relations. Political Geography, 27(1), 74-95. https://doi.org/10.1016/j.polgeo.2007.06.010

Kirby, A. (2019). Jane Jacobs and the limits to experience. Cities, 91, 17-22. https://doi.org/10.1016/j.cities.2018.01.021

Mattson, G. (2015). Bar districts as subcultural amenities. City, Culture and Society, 6(1), 1-8. https://doi.org/10.1016/j. ccs.2015.01.001

Mehmood, A. (2016). Of resilient places: Planning for urban resilience. European Planning Studies, 24(2), 407-419. https://doi.org/10.1080/09654313.2015.1082980

Middleton, J. (2009). Stepping in time: Walking time and space in the city. Environment \& Planning A, 41(8), 1943-1961. https://doi.org/10.1068/a41170

Mulicek, O., Osman, R., \& Seidenglanz, D. (2016). Time-space rhythms of the city-The industrial and postindustrial Brno. Environment \& Planning A, 48(1), 115-131. https://doi.org/10.1177/0308518X15594809

Nagy, E. (2001). Winners and losers in the transformation of city centre retailing in East Central Europe. European Urban and Regional Studies, 8(4), 340-348. https://doi.org/10.1177/096977640100800406

Ozuduru, B., Varol, C., \& Ercoskun, O. Y. (2014). Do shopping centers abate the resilience of shopping streets? The co-existence of both shopping venues in Ankara, Turkey. Cities, 36, 145-157. https://doi.org/10.1016/j.cities.2012. 10.003

Paiva, D., Cachinho, H., \& Barata-Salgueiro, T. (2017). The pace of life and temporal resources in a neighborhood of an Edge City. Time and Society, 26(1), 28-51. https://doi.org/10.1177/0961463X15596704

Parker, C., Ntounis, N., Millington, S., Quin, S., \& Castillo-Villar, F. R. (2017). Improving the vitality and viability of the UK High Street by 2020: Identifying priorities and a framework for action. Journal of Place Management and Development, 10(4), 310-348. https://doi.org/10.1108/JPMD-03-2017-0032

Resuloglu, C. (2011) The Tunali Hilmi Avenue, 1950s-1980s: The formation of a public place in Ankara. Unpublished Ph.D. thesis, Faculty of Architecture, METU.

Spaans, M., \& Waterhout, B. (2017). Building up resilience in cities worldwide-Rotterdam as participant in the 100 Resilient Cities Programme. Cities, 61, 109-116. https://doi.org/10.1016/j.cities.2016.05.011 
Staeheli, L. A., \& Mitchell, D. (2007). Locating the public in research and practice. Progress in Human Geography, 31 (6), 792-811. https://doi.org/10.1177/0309132507083509

Sutton, S. A. (2010). Rethinking commercial revitalization: A neighborhood small business perspective. Economic Development Quarterly, 24(4), 352-371. https://doi.org/10.1177/0891242410370679

Talen, E., \& Jeong, H. (2019). What is the value of 'main street'? Framing and testing the arguments. Cities, 92, 208-218. https://doi.org/10.1016/j.cities.2019.03.023

Vale, L. J. (2014). The politics of resilient cities: Whose resilience and whose city? BRI-Building Research and Information, 42(2), 191-201. https://doi.org/10.1080/09613218.2014.850602

Vergunst, J. (2010). Rhythms of walking: History and presence in a city street. Space and Culture, 13(4), 376-388. https://doi.org/10.1177/1206331210374145

Weichselgartner, J., \& Kelman, I. (2014). Challenges and opportunities for building urban resilience. Itu Alz, 11(2), 20-35. https://discovery.ucl.ac.uk/id/eprint/1437000/

Wrigley, N., \& Dolega, L. (2011). Resilience, fragility, and adaptation: New evidence on the performance of UK High Streets during global economic crisis and its policy implications. Environment \& Planning A, 43(10), $2337-2363$. https://doi.org/10.1068/a44270

Wrigley, N., \& Lambiri, D. (2014). High-street performance and evaluation: A brief guide to the evidence. University of Southampton.

Wunderlich, F. M. (2008). Walking and rhythmicity: Sensing urban space. Journal of Urban Design, 13(1), 125-139. https://doi.org/10.1080/13574800701803472

Zardini, M. (2005). Toward a sensorial urbanism. In M. Zardini (Ed.), Sense of the city: An alternate approach to urbanism (pp. 17-27). Canadian Center for Architecture, Lars Muller Publishers.

Zukin, S. (2012). The social production of urban cultural heritage: Identity and ecosystem on an Amsterdam shopping street. City, Culture and Society, 3(4), 281-291. https://doi.org/10.1016/j.ccs.2012.10.002 